\title{
Effect of PVA Concentration on Structure and Performance of Precipitated Iron- Based Catalyst for Fischer-Tropsch Synthesis
}

\author{
Cailian Ma, ${ }^{a}$ Guanghua Dong, ${ }^{a}$ Xia Liu ${ }^{a}$ and Jiangang Chen $*, b$ \\ ${ }^{a}$ Shanxi Institute of Energy, Jinzhong, 030600 Shanxi, P. R. China \\ ${ }^{b}$ State Key Laboratory of Coal Conversion, Institute of Coal Chemistry, \\ Chinese Academy of Sciences, 030001 Taiyuan, P. R. China
}

\begin{abstract}
$\mathrm{Fe}_{2} \mathrm{O}_{3}$ catalysts were prepared by co-precipitation method with the assistance of polyvinyl alcohol (PVA) for Fischer-Tropsch synthesis. Effects of PVA concentration on structure and performance of the catalyst were investigated in a fixed reactor at $230-310^{\circ} \mathrm{C}, 1.5 \mathrm{MPa}, 2000 \mathrm{~h}^{-1}$, and syngas $\mathrm{H}_{2} / \mathrm{CO}=2.0$. The catalysts were characterized by $\mathrm{N}_{2}$ adsorption, scanning electron microscopy (SEM), transmission electron microscopy (TEM), X-ray diffraction (XRD), $\mathrm{H}_{2}$ or CO temperature-programmed reduction (TPR) and $\mathrm{H}_{2}$ temperature-programmed desorption ( $\left.\mathrm{H}_{2}-\mathrm{TPD}\right)$, Fourier transform infrared (FTIR) spectra and thermogravimetric analysis (TGA). It was found that there was strong interaction between Fe and PVA, which controlled the structure of the catalyst. Among the catalysts investigated, the catalyst prepared with $15 \mathrm{wt}$ \% PVA exhibited better catalytic performance due to the dispersion of iron oxides and the formation of the more active phase on the catalyst. Meanwhile, this catalyst showed the high selectivity to heavy hydrocarbons and satisfactory thermal stability.
\end{abstract}

Keywords: Fischer-Tropsch synthesis, iron-based catalyst, PVA concentration, structure, stability

\section{Introduction}

Fischer-Tropsch synthesis (FTS), an efficient technology to convert syngas into liquid fuels and chemicals, has attracted great interest due to the shrinking of the petroleum resource in the past decades. ${ }^{1}$ Iron-based catalysts have attracted considerable focus, thanks to their low cost, high activity and excellent water-gas-shift reactivity, which match coal gasification with low $\mathrm{H}_{2} / \mathrm{CO}$ ratio. ${ }^{2}$ Remarkably, three principal challenges are posed for iron-based FTS catalyst: activity, selectivity and stability. ${ }^{3}$

It is well known that the activity, selectivity and stability of FTS catalysts rely strongly on the texture and surface properties of the resultant catalysts. ${ }^{4}$ Most of all, the pore size of catalyst is one of the key factors, which has significant effect on the mass transfer of reactants and products, ${ }^{5}$ the re-adsorption of the $\alpha$-alkene, and the chemisorption ratio of $\mathrm{H}_{2}$ on the surface active sites exposed. ${ }^{6}$ Therefore, these factors are vital for the performance of catalyst in the FTS. For instance, smaller pore size of catalyst can afford high Brunauer, Emmett and

*e-mail: chenjg19@163.com
Teller (BET) surface area and dispersion of the catalyst. However, diffusion effects of products were limited, resulting in light hydrocarbons as the main product for excessive hydrogenation. In contrast, the larger pore size of catalyst can facilitate the diffusion of products, and thus products of heavy hydrocarbons are obtained. ${ }^{7}$ Tao et al. ${ }^{8}$ proposed that the FTS catalytic activity and product selectivity rely strongly on the pore size distribution of the catalysts. Xiong et al. ${ }^{9}$ found that $\mathrm{CO}$ conversion increased and then decreased with the pore size in the range studied. Sun and co-workers ${ }^{10,11}$ reported that the FTS catalytic performances were closely correlated to the pore sizes of the mesoporous zirconia.

In general, the preparation process has a significant effect on the physical property and catalytic performance of the catalyst. The iron-based catalysts were mainly prepared by the co-precipitation, ${ }^{4,9}$ fusion, ${ }^{3}$ sol-gel, ${ }^{12}$ microemulsions ${ }^{13}$ method and so on. ${ }^{14,15}$ However, the regulating and controlling of the pore size and the morphology remains a challenge for the co-precipitation method. Microemulsions, defined as a system consisting of water, oil and surfactant, are used for synthesizing nanoparticles. ${ }^{13}$ The nanoparticles obtained from 
microemulsions exhibit large surface areas, but have small pore size. In order to modulate pore size of resultant, co-precipitation with the assistance of surfactant method was adopted to prepare catalyst. In the preparation process, the size and shape of resultant can be controlled by adopting surfactants, as powerful agents, for the strong interaction between surfactants and crystal surfaces. ${ }^{16}$ In addition, surfactants are attractive as template for controlling to growing new crystalline materials in the preparation process, which have shown potential applications in many fields such as catalysis, ${ }^{17}$ electrochemistry, ${ }^{18}$ and so on. ${ }^{19,20}$ Luo et al. ${ }^{17}$ investigated the $\mathrm{CuO}-\mathrm{CeO}_{2}$ catalysts prepared by a surfactant-templated method, and they found that the $\mathrm{CuO}-\mathrm{CeO}_{2}$ catalysts showed high catalytic activity for selective oxidation of $\mathrm{CO}$ in excess $\mathrm{H}_{2}$ at relatively low temperature. Fang and co-workers ${ }^{20}$ recently prepared the $\mathrm{Cu} / \mathrm{ZnO} / \mathrm{Al}_{2} \mathrm{O}_{3}(\mathrm{CZA})$ catalysts by two-step precipitation method with the assistance of the surfactant. They found that the 2T-CZA catalyst, prepared with addition of $2 \mathrm{wt} . \%$ tetraethylammonium hydroxide (TEAH) in the course of the co-precipitation of $\mathrm{Cu}^{2+}$ and $\mathrm{Zn}^{2+}$, exhibited satisfactory stability. However, to the best of our knowledge, the effect of co-precipitation method with the assistance of surfactant on the FTS performance of iron catalyst was rarely reported.

In this work, a series of iron-based catalysts with different polyvinyl alcohol (PVA) concentrations were prepared by co-precipitation method with the assistance of PVA, and systematically investigated the effect of PVA concentrations on the structure, the catalytic activity and the stability.

\section{Experimental}

\section{Catalyst preparation}

Reagents were all of analytically pure (AR) grade. Water used in the synthesis and washing was deionized. The iron catalysts with different PVA concentrations were prepared by co-precipitation method. For a typical synthesis, $30 \mathrm{mmol} \mathrm{Fe}\left(\mathrm{NO}_{3}\right)_{3} \cdot 9 \mathrm{H}_{2} \mathrm{O}$ was added into a solution of PVA $(0,5,15,25$ wt. $\%)$. After the mixture was stirred for $0.5 \mathrm{~h}$, ammonium solution (20 wt. \%) was simultaneously added into the precipitated vessel maintained at a constant $\mathrm{pH}$ value of $8.5 \pm 0.1$. The obtained precipitates were aged for $2 \mathrm{~h}$ and washed with deionized water. After that, the catalyst precursors were dried at $100{ }^{\circ} \mathrm{C}$ for $6 \mathrm{~h}$, followed by calcination at $500{ }^{\circ} \mathrm{C}$ for $6 \mathrm{~h}$ in air. In this study, the catalysts prepared by co-precipitation with $0,5,15$ and 25 wt.\% of PVA were marked as $\mathrm{Fe}_{2} \mathrm{O}_{3}, \mathrm{Fe}_{2} \mathrm{O}_{3}$-PVA-1, $\mathrm{Fe}_{2} \mathrm{O}_{3}$-PVA-2 and $\mathrm{Fe}_{2} \mathrm{O}_{3}$-PVA-3, respectively.

\section{Catalyst characterization}

Brunauer-Emmett-Teller (BET) surface area of the catalysts was measured by nitrogen sorption at $-195.8{ }^{\circ} \mathrm{C}$ with a TriStar 3000 Gas Absorption Analyzer. The pore diameter was calculated by applying the Barret-JoynerHalenda method $(\mathrm{BJH})$ to the adsorption branches of the $\mathrm{N}_{2}$ isotherms. The samples were degassed at $200{ }^{\circ} \mathrm{C}$ and 6.7 $\mathrm{Pa}$ for $2 \mathrm{~h}$ prior to the measurement.

The morphology of catalysts was investigated by scanning electron microscopy (SEM) (JSM-6701F). The samples were prepared through anchoring on the surface of the conducting resin, and then needed to be treated with spray-gold before observing.

Transmission electron microscopy (TEM) images of the catalysts were obtained by using a JEM 2010 microscope operating at $200 \mathrm{kV}$. The catalysts were dispersed in ethanol and mounted on a carbon foil supported on a copper grid.

$\mathrm{X}$-ray diffraction (XRD) measurements were carried out with a D/max-RA X-ray diffractometer (Rigaku), equipped with $\mathrm{Cu} K \alpha$ radiation $(\lambda=1.5406 \AA)$ at $40 \mathrm{kV}$ and $150 \mathrm{~mA}$. The measurements were made at room temperature in the $2 \theta$ range of $10-80^{\circ}$ with a scanning rate of 2 or $4^{\circ} \mathrm{min}^{-1}$.

$\mathrm{H}_{2}$ temperature-programmed reduction $\left(\mathrm{H}_{2}-\mathrm{TPR}\right)$ experiment was performed in a conventional atmospheric quartz reactor ( $5 \mathrm{~mm}$ internal diameter, i.d.). A flow of 5:95 (v/v) $\mathrm{H}_{2} / \mathrm{Ar}$, maintained at a flow of $50 \mathrm{~mL} \mathrm{~min}^{-1}$, was used as the reduction gas, and the TPR profiles were recorded by using the response of the thermal conductivity detector (TCD) of the effluent gas. Typically, $50 \mathrm{mg}$ samples were loaded and reduced by 5:95 (v/v) $\mathrm{H}_{2} / \mathrm{Ar}$, from the temperature rising from room temperature to $1000{ }^{\circ} \mathrm{C}$ at a rate of $10{ }^{\circ} \mathrm{C} \mathrm{min}^{-1}$.

CO-TPR experiment was carried out in a Micromeritics AutoChem II 2920 analyzer. In CO-TPR experiment, about $50 \mathrm{mg}$ of catalyst was loaded in an atmospheric quartz reactor $(5 \mathrm{~mm}$ i.d.). The catalyst sample heated in a flow of 5:95 (v/v) CO/He from room temperature to $500{ }^{\circ} \mathrm{C}$ at a heating rate of $10{ }^{\circ} \mathrm{C} \mathrm{min}^{-1}$, and the flow rate of gases was $50 \mathrm{~mL} \mathrm{~min}{ }^{-1}$. The reduction products were analyzed by TCD.

$\mathrm{H}_{2}$-TPD experiments were performed with $\mathrm{Ar}$ as carrier gas at a flow rate of $50 \mathrm{~mL} \mathrm{~min}{ }^{-1} .200 \mathrm{mg}$ of catalyst was charged into the quartz reactor. The catalyst was at first reduced with $\mathrm{H}_{2}$ at $350{ }^{\circ} \mathrm{C}$ for $10 \mathrm{~h}$. The catalyst sample was purged with $\mathrm{Ar}$ and calcined in situ at $350{ }^{\circ} \mathrm{C}$ for $1 \mathrm{~h}$ to remove the adsorbed species. In the following steps, $\mathrm{H}_{2}$ adsorption on catalyst was performed at room temperature for $30 \mathrm{~min}$, and then the sample was purged with the carrier gas for $30 \mathrm{~min}$ to remove the weakly adsorbed species. 
Subsequently, the TPD was started from room temperature to $900{ }^{\circ} \mathrm{C}$ at a heating rate of $10{ }^{\circ} \mathrm{C} \mathrm{min}^{-1}$.

Fourier transform infrared (FTIR) spectra were recorded in the $400-4000 \mathrm{~cm}^{-1}$ range with a Bruker Vertex 70 FT-IR, using the $\mathrm{KBr}$ pellet technique. The pellets were prepared by a $\mathrm{KBr} / \mathrm{sample}$ weight ratio of 200/1.

Thermogravimetric analysis (TGA) was conducted on a thermogravimetric analyzer of Setsys Evolution TGA $16 / 18$ in nitrogen atmosphere from ambient temperature to $650{ }^{\circ} \mathrm{C}$ with a heating rate of $10^{\circ} \mathrm{C} \mathrm{min}^{-1}$.

\section{Catalytic activity}

The FTS performance of the catalysts was tested in a stainless steel fixed-bed reactor with inner diameter of $12 \mathrm{~mm}$. A $2 \mathrm{~mL}$ of catalyst (60-80 mesh) was diluted with $4 \mathrm{~mL}$ of quartz granules (60-80 mesh) and then loaded into the reactor for all the reaction tests. The mass of catalyst is listed in Table 1. The remaining volume of the reactor tube was filled with quartz granules. All the catalysts were activated with syngas $\left(\mathrm{H}_{2} / \mathrm{CO}=2.0\right)$ at $280{ }^{\circ} \mathrm{C}$, $0.30 \mathrm{MPa}$, and $1000 \mathrm{~h}^{-1}$ for $24 \mathrm{~h}$. The reaction conditions were maintained at $1.5 \mathrm{MPa}, 2000 \mathrm{~h}^{-1}$, and $\mathrm{H}_{2} / \mathrm{CO}=2.0$. Wax was collected with a hot trap and the liquid products were collected in a cold trap. The gas effluents were analyzed on-line by using Carbosieve-packed column with TCD. The gas hydrocarbons were analyzed on-line using Porapack-Q column with FID. Oil and wax were analyzed offline in OV-101 capillary columns. $5 \% \mathrm{~N}_{2}$ was added to syngas as an internal standard. After reaction, used catalysts were cooled down in Ar and passivated by $\mathrm{CO}_{2}$ for $1.5 \mathrm{~h}$ at room temperature, and the flow rate of gases was $30 \mathrm{~mL} \mathrm{~min}^{-1}$. The carbon balance and mass balance were $100 \pm 5 \%$.

\section{Results and Discussion}

Textural properties of catalysts

The $\mathrm{N}_{2}$ physisorption was carried out to evaluate the textural properties of the $\mathrm{Fe}_{2} \mathrm{O}_{3}, \mathrm{Fe}_{2} \mathrm{O}_{3}$-PVA-1, $\mathrm{Fe}_{2} \mathrm{O}_{3}$-PVA-2 and $\mathrm{Fe}_{2} \mathrm{O}_{3}$-PVA-3 catalysts. The $\mathrm{N}_{2}$ adsorption-desorption for the $\mathrm{Fe}_{2} \mathrm{O}_{3}$ catalyst (Figure 1) shows a typical type-IV isotherm with type $\mathrm{H} 1$ hysteresis loop, demonstrating mesoporous characteristics for $\mathrm{Fe}_{2} \mathrm{O}_{3}$ material. Moreover, the mesoporous $\mathrm{Fe}_{2} \mathrm{O}_{3}$ exhibits a narrow pore size distribution centered at $11.8 \mathrm{~nm}$ calculated from $\mathrm{BJH}$ method (inset of Figure 1). It is worth noting that the $\mathrm{Fe}_{2} \mathrm{O}_{3}$-PVA catalyst shows a type-IV isotherms with type $\mathrm{H} 3$ hysteresis loop (Figure 1), indicating that the retention of well-defined slit-like mesostructure. In addition, the pore size of $\mathrm{Fe}_{2} \mathrm{O}_{3}$-PVA catalyst is much larger than that of the $\mathrm{Fe}_{2} \mathrm{O}_{3}$ catalyst (inset of Figure 1 and Table 1). According to the data in Table 1, the BET surface area of $\mathrm{Fe}_{2} \mathrm{O}_{3}$-PVA-1, $\mathrm{Fe}_{2} \mathrm{O}_{3}$-PVA-2 and $\mathrm{Fe}_{2} \mathrm{O}_{3}$-PVA-3 catalysts suffer from an evidently decrease compared with that of the $\mathrm{Fe}_{2} \mathrm{O}_{3}$ catalyst, probably owing to the $\mathrm{FeOOH}$ precursors could selfassemble with the assistance of PVA, ${ }^{21,22}$ but they possess larger pore size, which helps the diffusion of products.

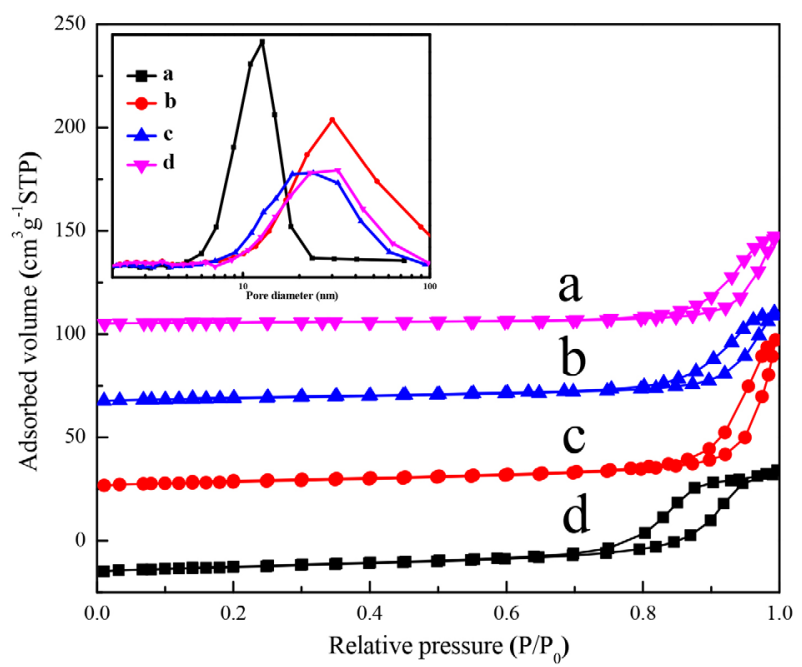

Figure 1. Nitrogen adsorption-desorption isotherms and BJH pore diameter distribution plot (inset, branch of desorption) of the (a) $\mathrm{Fe}_{2} \mathrm{O}_{3}$; (b) $\mathrm{Fe}_{2} \mathrm{O}_{3}$-PVA-1; (c) $\mathrm{Fe}_{2} \mathrm{O}_{3}$-PVA-2; (d) $\mathrm{Fe}_{2} \mathrm{O}_{3}$-PVA-3 catalysts.

\section{SEM and TEM results}

The SEM images of the catalysts as-prepared are shown in Figure 2. For the $\mathrm{Fe}_{2} \mathrm{O}_{3}$ catalyst (Figure 2a), the samples

Table 1. Physical properties of the catalysts as-prepared

\begin{tabular}{lccccc}
\hline Catalyst & Mass of catalyst / g & $\begin{array}{c}\text { BET surface area / } \\
\left(\mathrm{m}^{2} \mathrm{~g}^{-1}\right)\end{array}$ & $\begin{array}{c}\text { Pore volume / } \\
\left(\mathrm{cm}^{3} \mathrm{~g}^{-1}\right)\end{array}$ & $\begin{array}{c}\text { Average pore size / } \\
\mathrm{nm}\end{array}$ & $\begin{array}{c}\text { Crystallite size / } \\
\mathrm{nm}\end{array}$ \\
\hline $\mathrm{Fe}_{2} \mathrm{O}_{3}$ & 2.66 & 19.75 & 0.08 & 13.75 & 19.76 \\
$\mathrm{Fe}_{2} \mathrm{O}_{3}$-PVA-1 & 2.49 & 16.22 & 0.11 & 27.94 & 29.58 \\
$\mathrm{Fe}_{2} \mathrm{O}_{3}$-PVA-2 & 2.35 & 11.46 & 0.07 & 24.06 & 29.92 \\
$\mathrm{Fe}_{2} \mathrm{O}_{3}$-PVA-3 & 2.51 & 8.78 & 0.07 & 31.05 & 30.46 \\
\hline
\end{tabular}

${ }^{\mathrm{a}}$ Calculated from the Scherrer equation according to the (104) diffraction peak of $\mathrm{Fe}_{2} \mathrm{O}_{3}$; BET: Brunauer-Emmett-Teller. 
mainly consisted of spherical-shaped particles with sharp edges presenting irregular shaped. ${ }^{23}$ Some of the smaller particles are attached to the surface of the larger ones. In the case of the $\mathrm{Fe}_{2} \mathrm{O}_{3}$-PVA-1 catalyst, the particles show short rod shape (Figure 2b), attributed to the particle reforming after addition PVA in preparing. Meanwhile, the particle size of the $\mathrm{Fe}_{2} \mathrm{O}_{3}$-PVA-1 catalyst is larger than that of the $\mathrm{Fe}_{2} \mathrm{O}_{3}$ catalyst. With a further increase of PVA concentration, $\mathrm{Fe}_{2} \mathrm{O}_{3}$-PVA-2 catalyst displays loosely uniform flowery shape consisting of flake shape (Figure 2c). However, the $\mathrm{Fe}_{2} \mathrm{O}_{3}$-PVA-3 catalyst exhibits destruction of flowery shape consisting of flake shape (Figure 2d). The $\mathrm{Fe}_{2} \mathrm{O}_{3}$-PVA-2 catalyst is loosely uniform flowery shape in the morphology requirement for easy gas diffusion and mass transport during FTS reaction. In the preparation process, the destruction of the spherical shape should be responsible for the different particles shape, which is closely related to the amount of PVA contained in the precursor obtained from the precipitation reaction.

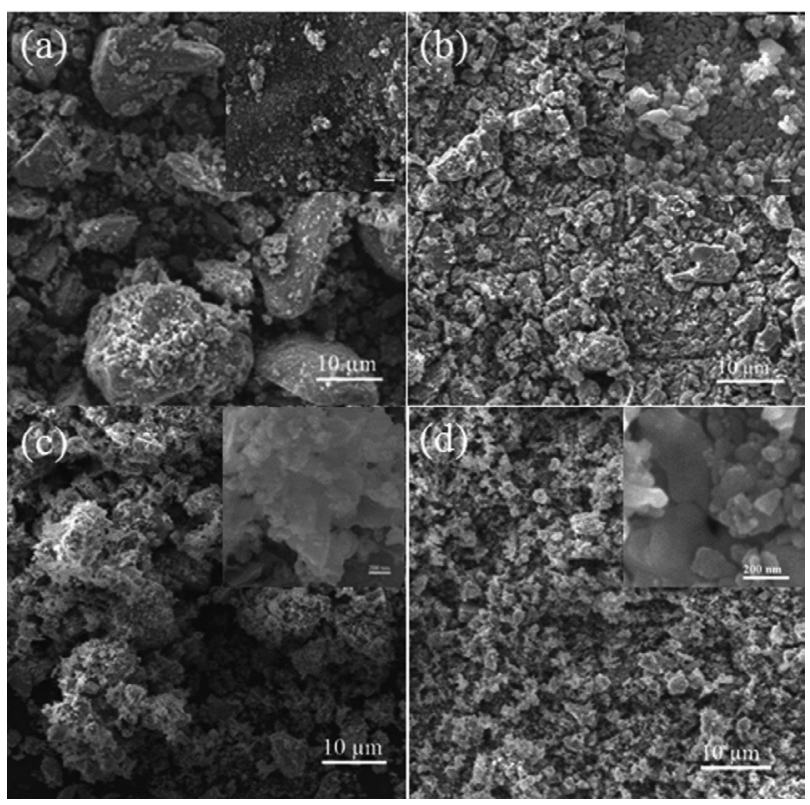

Figure 2. SEM images of (a) $\mathrm{Fe}_{2} \mathrm{O}_{3}$; (b) $\mathrm{Fe}_{2} \mathrm{O}_{3}$-PVA-1; (c) $\mathrm{Fe}_{2} \mathrm{O}_{3}$-PVA-2; (d) $\mathrm{Fe}_{2} \mathrm{O}_{3}$-PVA-3 catalysts.

The TEM images of the catalysts as-prepared are shown in Figure 3. $\mathrm{Fe}_{2} \mathrm{O}_{3}$ catalyst has a particle diameter of around $20 \mathrm{~nm}$ (Figure 3a, inset). $\mathrm{Fe}_{2} \mathrm{O}_{3}$-PVA-1 is in the shape of rods with a width of about $35 \mathrm{~nm}$ and a length of 60-300 nm (Figure 3b, inset). Meanwhile, nanoparticles of $\mathrm{Fe}_{2} \mathrm{O}_{3}$-PVA-2 catalyst (about $35 \mathrm{~nm}$ ) arrange at random and form a loosely flake microstructure (Figure $3 \mathrm{c}$, inset). However, nanoparticles of $\mathrm{Fe}_{2} \mathrm{O}_{3}$-PVA-3 catalyst (about $50 \mathrm{~nm}$ ) have a relatively dense and irregular flake structure (Figure $3 \mathrm{~d}$, inset). The results demonstrate that structure and particle size of the $\mathrm{Fe}_{2} \mathrm{O}_{3}$-PVA catalyst can be controlled by tuning PVA concentrations during the catalyst preparation process. Different structure of catalyst will further influences dispersion of catalyst.

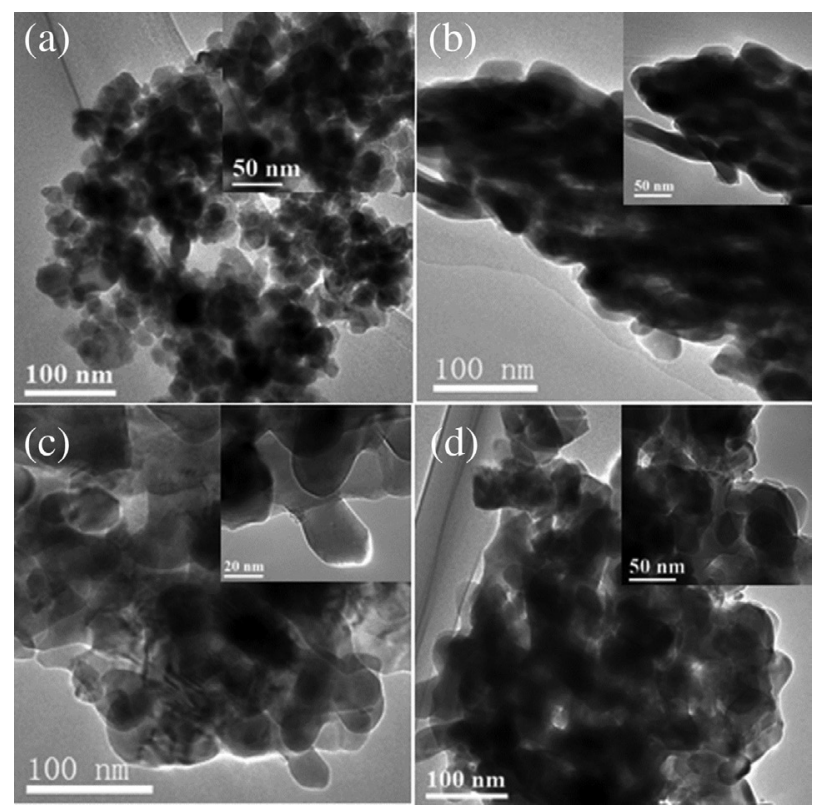

Figure 3. TEM images of (a) $\mathrm{Fe}_{2} \mathrm{O}_{3}$; (b) $\mathrm{Fe}_{2} \mathrm{O}_{3}$-PVA-1; (c) $\mathrm{Fe}_{2} \mathrm{O}_{3}$-PVA-2; (d) $\mathrm{Fe}_{2} \mathrm{O}_{3}$-PVA-3 catalysts.

\section{Crystallite structure of catalysts}

The XRD patterns of the catalysts as-prepared with different PVA concentrations are presented in Figure 4a. It is obvious that the only detectable phase in all of catalysts as-prepared is well-crystallized hematite (JCPDS Card No. 033-0664) with characteristic diffraction peaks at $2 \theta$ values of $24.2,33.1,35.6,40.8,49.52,54.0,57.6,62.5$ and $64.0^{\circ}$. It is obvious that the average crystalline size of $\alpha-\mathrm{Fe}_{2} \mathrm{O}_{3}$ of $\mathrm{Fe}_{2} \mathrm{O}_{3}$-PVA catalyst (about $30 \mathrm{~nm}$ ) is larger than that of the $\mathrm{Fe}_{2} \mathrm{O}_{3}$ catalyst (about $20 \mathrm{~nm}$ ). It implies that

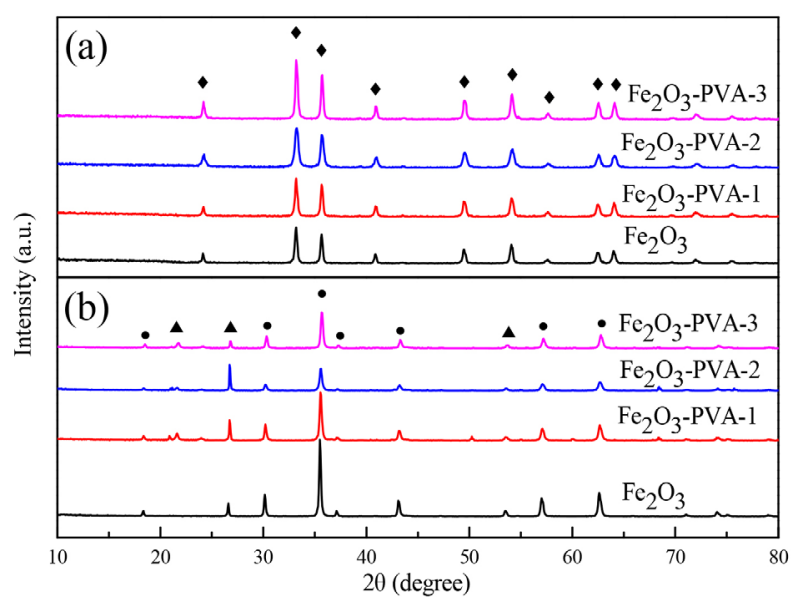

Figure 4. XRD pattern of catalysts: (a) as-prepared and (b) after reaction: $(\bullet)$ hematite; $(\bullet)$ magnetite; $(\boldsymbol{\Delta})$ quartz. 
the addition of PVA in the catalyst preparation process can promote the aggregation of $\alpha-\mathrm{Fe}_{2} \mathrm{O}_{3}$ crystallite. In addition, the diffraction peak intensity of $\alpha-\mathrm{Fe}_{2} \mathrm{O}_{3}$ increases with the increase of PVA concentration. This is consistent with the observed decrease in the catalyst surface area.

The XRD patterns of the catalysts after reaction are shown in Figure $4 b$. There are several diffraction peaks assigned to dilute quartzes for all catalysts. It is obvious that the spent $\mathrm{Fe}_{2} \mathrm{O}_{3}$ catalyst and $\mathrm{Fe}_{2} \mathrm{O}_{3}$-PVA catalyst show only magnetite (JCPDS Card No. 085-1436) phase with characteristic diffraction peaks at $2 \theta$ values of 35.5 , 43.1, 57.0 and $62.6^{\circ}$. All catalysts present sharp and strong intensity. Since the iron carbides can be oxidized to $\mathrm{Fe}_{3} \mathrm{O}_{4}$, especially for the unsupported iron catalyst, ${ }^{24-26}$ it is impossible to be observed in the XRD patterns of all catalysts. In addition, the XRD patterns also show that the diffraction peak intensities of $\mathrm{Fe}_{3} \mathrm{O}_{4}$ clearly decrease with the increase of PVA concentration and pass through a minimum at the PVA concentration of $15 \mathrm{wt}$. \%. It indicates that the catalyst with addition of PVA during catalyst preparing process inhibits formation of the magnetite in FTS reaction. It is well known that although magnetite is the most active phase for the water-gas-shift (WGS) reaction on iron-based catalysts, ${ }^{27}$ this phase is not active for FTS. Davis and co-workers ${ }^{28}$ reported that magnetite alone showed no initial activity when being exposed to syngas.

\section{Reduction and carburization behaviors}

Catalysts reduction and carburization behaviors were studied by $\mathrm{H}_{2}$-TPR and CO-TPR. The $\mathrm{H}_{2}$-TPR profiles are shown in Figure 5a. It is reasonable to assume that only the $\mathrm{Fe}_{2} \mathrm{O}_{3}$ phase is primarily present after calcination based on the similar TPR profiles for all catalysts. As shown in Figure 5a, the profile of $\mathrm{Fe}_{2} \mathrm{O}_{3}$ and $\mathrm{Fe}_{2} \mathrm{O}_{3}$-PVA catalysts shows multiple reduction peaks, which can be assigned to two different reduction stages of iron oxides. The first stage (lower-temperature reduction peak) is assigned to the transformations of $\mathrm{Fe}_{2} \mathrm{O}_{3} \rightarrow \mathrm{Fe}_{3} \mathrm{O}_{4}$, whereas the second stage (higher-temperature reduction peaks) represents the transformation of $\mathrm{Fe}_{3} \mathrm{O}_{4} \rightarrow \mathrm{Fe}^{29}$ A significant delay in the first reduction peak temperature is observed for $\mathrm{Fe}_{2} \mathrm{O}_{3}$-PVA catalyst compared with the $\mathrm{Fe}_{2} \mathrm{O}_{3}$ catalyst. As the PVA concentration increased, the first reduction peak of catalyst shifted gradually to higher temperature. Fang and co-workers ${ }^{20}$ reported that with the introduction of the surfactant in the course of preparing catalyst, the first reduction peak temperature of resultant catalyst shifted to higher temperature. Therefore, the results confirm that the addition of PVA in the catalyst preparation process can inhibit the reduction of the catalyst in $\mathrm{H}_{2}$ atmosphere.

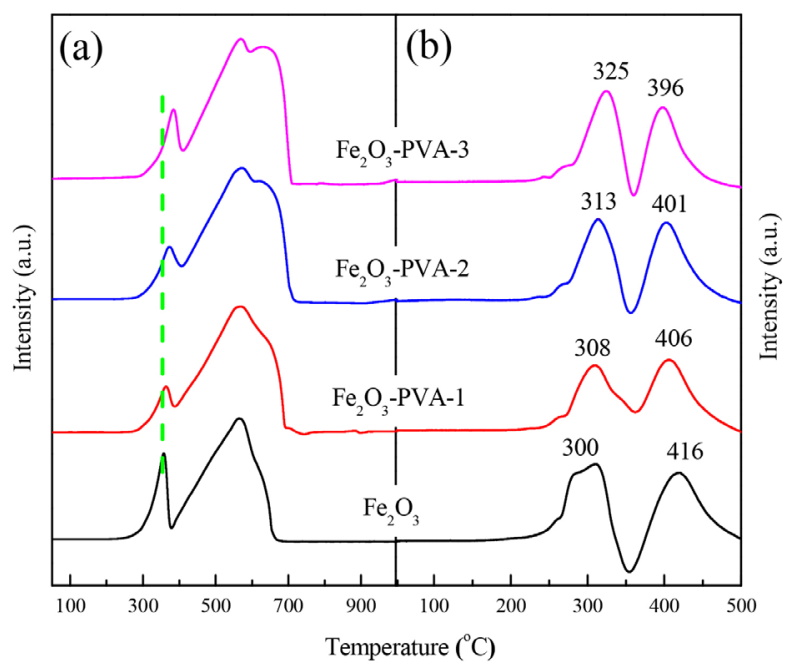

Figure 5. TPR profiles of catalysts: (a) $\mathrm{H}_{2}-\mathrm{TPR}$ and (b) CO-TPR.

CO-TPR profiles of the catalysts are displayed in Figure 5b. It is found that all catalysts have two well-separated peaks, indicating that the catalysts are reduced and carburized via two steps, hematite $\left(\mathrm{Fe}_{2} \mathrm{O}_{3}\right)$ to magnetite $\left(\mathrm{Fe}_{3} \mathrm{O}_{4}\right)$ and magnetite to iron carbides. ${ }^{30,31}$ The reduction temperature of $\mathrm{Fe}_{2} \mathrm{O}_{3}$-PVA catalyst shifts to higher temperature as compared with $\mathrm{Fe}_{2} \mathrm{O}_{3}$ catalyst, while the carburization temperature of $\mathrm{Fe}_{2} \mathrm{O}_{3}$-PVA catalyst shifts to lower temperature as compared with $\mathrm{Fe}_{2} \mathrm{O}_{3}$ catalyst. Moreover, as PVA concentration increases, the first peak shifts to higher temperature gradually and the second peak shifts to lower temperature. The results indicate that the addition of PVA in the catalyst preparation process inhibits the reduction behaviors of iron oxides either in $\mathrm{H}_{2}$ or in $\mathrm{CO}$ atmosphere probably due to stronger iron oxides interaction, but promotes the carburization of the catalyst.

\section{Adsorption behaviors}

$\mathrm{H}_{2}$-TPD is used to investigate the effect of PVA on the $\mathrm{H}_{2}$ chemisorption behavior of catalysts (Figure 6). $\mathrm{H}_{2}$ desorption over all catalysts mainly occurs in two broad temperature ranges: below $400{ }^{\circ} \mathrm{C}$ and above $400{ }^{\circ} \mathrm{C}$. For the $\mathrm{Fe}_{2} \mathrm{O}_{3}$ catalyst two evident desorption peaks appear in $\mathrm{H}_{2}$-TPD curves: a broad peak at $150-350{ }^{\circ} \mathrm{C}$ and a sharp peak at ca. $650{ }^{\circ} \mathrm{C}$. In the case of $\mathrm{Fe}_{2} \mathrm{O}_{3}$-PVA-1 catalyst, the profile of $\mathrm{H}_{2}$ desorption below $400{ }^{\circ} \mathrm{C}$ is similar to that of $\mathrm{Fe}_{2} \mathrm{O}_{3}$ catalyst, while the intensity of peak at ca. $650{ }^{\circ} \mathrm{C}$ is higher than that of $\mathrm{Fe}_{2} \mathrm{O}_{3}$ catalyst. With increasing PVA concentration, the intensity of the peak at ca. $650^{\circ} \mathrm{C}$ at first increases, then passes a maximum at the PVA concentration of $15 \mathrm{wt} . \%$, and then decreases gradually. In addition, the peaks below $400{ }^{\circ} \mathrm{C}$ shift to higher temperatures, indicating 
that the hydrogen adsorption sites become more uneven with increasing PVA concentration.

Because of the heterogeneity of iron catalyst, catalyst includes numerous iron particles with various geometric shapes and sizes. Therefore, different surface structural can lead to the different $\mathrm{H}_{2}$-TPD profiles of the iron catalyst. ${ }^{29}$ Previous studies demonstrated that hydrogen adsorption over iron surfaces is weak at on-top or shallow hollow sites but stable at deep hollow or defect sites. ${ }^{32-34} \mathrm{H}_{2}$-TPD profiles in high-temperature regions (above $400{ }^{\circ} \mathrm{C}$ ), designated as $\mathrm{H}_{\gamma}$, which may correspond to hydrogen chemisorbed onto iron oxides. ${ }^{29,35-37} \mathrm{As}$ for the $\mathrm{H}_{2}$-TPD experiments, the desorption peaks at the different temperatures correspond to $\mathrm{H}$ adsorbed on different active sites, and the intensity of the corresponding peaks could indirectly reveal the relative amount of the active sites exposed on the reduced catalysts. For unsupported iron catalysts, the $\mathrm{H}_{2}$ desorption peak area may estimate the dispersion of catalyst. Clearly, the $\mathrm{H}_{2}$ desorption peak area of $\mathrm{Fe}_{2} \mathrm{O}_{3}$-PVA catalyst above $400{ }^{\circ} \mathrm{C}$ is larger than that of $\mathrm{Fe}_{2} \mathrm{O}_{3}$ catalyst, which are beneficial to the dispersion of iron and in turn may contribute to high catalytic activity of $\mathrm{Fe}_{2} \mathrm{O}_{3}$-PVA catalyst in FTS, especially for $\mathrm{Fe}_{2} \mathrm{O}_{3}$-PVA-2 catalyst. The results indicate that addition of PVA in catalyst preparation process apparently improves the dispersion of iron catalyst.

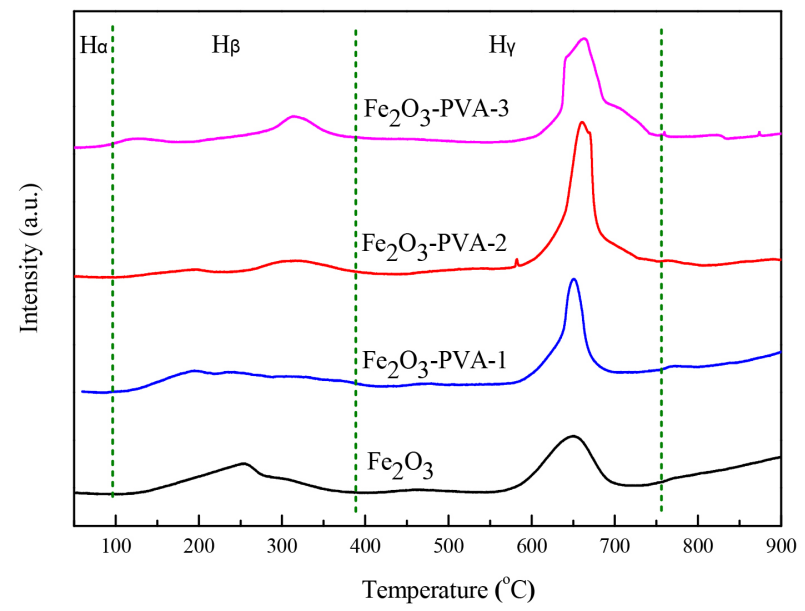

Figure 6. $\mathrm{H}_{2}$-TPD profiles of catalysts.

\section{FTIR and TGA}

As an organic assistant agent (PVA) used during the preparation of the iron catalysts, FTIR is performed to examine whether the organic species is completely removed by later calcination pretreatment at $500^{\circ} \mathrm{C}$. The FTIR results of the catalysts are shown in Figure 7. The vibrational bands attributed to the crystallization water molecules and the constitution water molecules are observed in the ranges of
3600-3200 and $1700-1550 \mathrm{~cm}^{-1},{ }^{38}$ respectively. In addition, the about $555 \mathrm{~cm}^{-1}$ band is attributed to the $\mathrm{Fe}-\mathrm{O}$ stretching vibration..$^{39}$ From the spectra, it can be found that the bands of catalysts with different PVA concentrations are the same. $\mathrm{Wu}$ and co-workers ${ }^{40}$ have reported that the PVA can be completely removed through the calcination at $450{ }^{\circ} \mathrm{C}$.

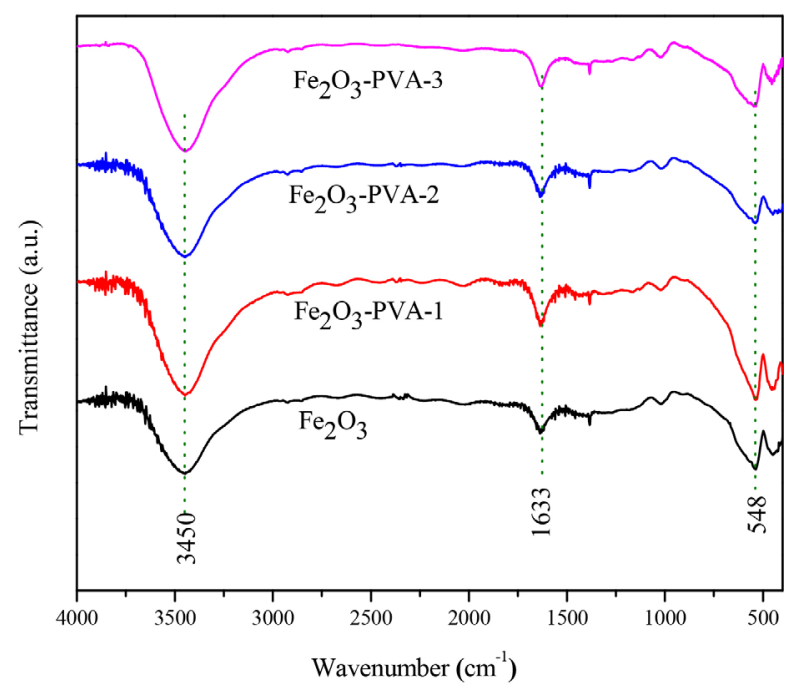

Figure 7. FTIR profiles of catalysts.

TGA analysis was performed to further examine whether the organic species (PVA) was completely removed by later calcination pretreatment at $500{ }^{\circ} \mathrm{C}$. As shown in Figure 8, for $\mathrm{Fe}_{2} \mathrm{O}_{3}$-PVA-3 catalyst, there is a significant weight loss of about $8.3 \%$ due to desorption of physisorbed water molecules from 100 to $300^{\circ} \mathrm{C}$. No further weight loss and no thermal effect are observed after $300^{\circ} \mathrm{C}$. But in the TGA curve of $\mathrm{Fe}_{2} \mathrm{O}_{3}$, there is weight loss of about $7.3 \%$ due to desorption of physisorbed water molecules from 100 to $300{ }^{\circ} \mathrm{C}$. In addition, a small weight loss of about $2 \%$ is observed in the temperature range of $300-520^{\circ} \mathrm{C}$,

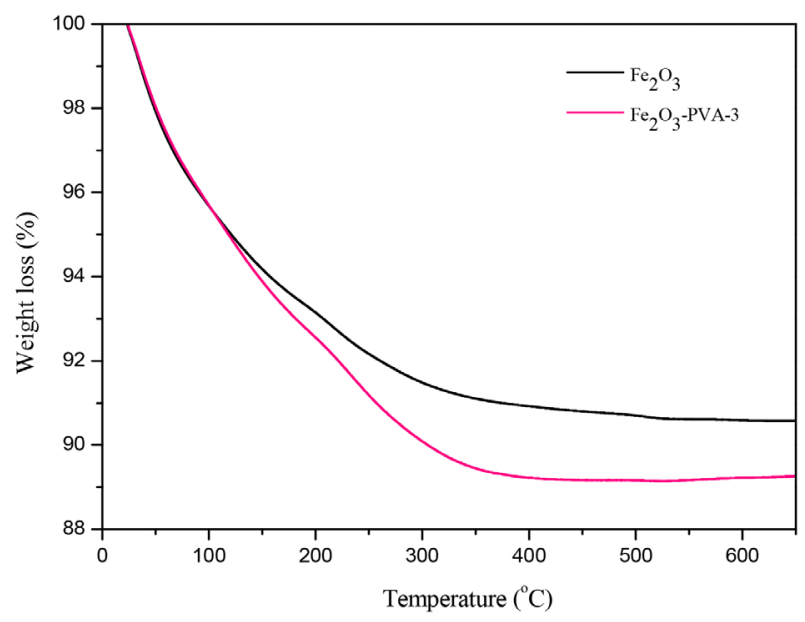

Figure 8. TGA profiles of catalysts. 
due to the condensation dehydration of surface hydroxyl groups. ${ }^{41}$ FTIR and TGA results suggest that the PVA can be completely removed through the calcination at $500^{\circ} \mathrm{C}$.

\section{FTS performance}

The activities of the $\mathrm{Fe}_{2} \mathrm{O}_{3}$ and $\mathrm{Fe}_{2} \mathrm{O}_{3}$-PVA catalysts are shown in Figure 9. The $\mathrm{CO}$ conversion was used as a measure of FTS activity; i.e., higher conversion implies higher catalyst activity. The $\mathrm{Fe}_{2} \mathrm{O}_{3}$-PVA-1, $\mathrm{Fe}_{2} \mathrm{O}_{3}$-PVA-2 and $\mathrm{Fe}_{2} \mathrm{O}_{3}$-PVA-3 catalysts with larger pore size exhibited the higher $\mathrm{CO}$ conversion than that of the $\mathrm{Fe}_{2} \mathrm{O}_{3}$ catalyst under the same reaction conditions. Furthermore, the $\mathrm{CO}$ conversion significantly increases with the increasing of PVA concentration and passes through a maximum at the PVA concentration of 15 wt. \%. The stability of catalysts is presented in Figure 10. The variation of the activity with time on stream (TOS) can be used as an indicator of catalyst stability. It can be found that the initial $\mathrm{CO}$ conversion of $\mathrm{Fe}_{2} \mathrm{O}_{3}$ catalyst is high. However, its stability is very poor. The CO conversion quickly decreases from about $55 \%$ at the beginning of the reaction to about $30 \%$ at a TOS of $312 \mathrm{~h}$. With the addition of PVA in catalyst preparation, the reaction behavior of $\mathrm{Fe}_{2} \mathrm{O}_{3}$-PVA-2 catalyst is different from that of $\mathrm{Fe}_{2} \mathrm{O}_{3}$ catalyst, while its steady $\mathrm{CO}$ conversion is quickly stabilized at a relatively high level. The BET results indicate that pore size of $\mathrm{Fe}_{2} \mathrm{O}_{3}$-PVA catalyst is much larger than that of the $\mathrm{Fe}_{2} \mathrm{O}_{3}$ catalyst. Anderson et al. ${ }^{42}$ reported that the FTS activity and selectivity of catalyst could be affected by their pore sizes. Khodakov et al. ${ }^{43}$ suggested that lower reducibility of small particles is likely to be one of the reasons responsible for the lower Fischer-Tropsch reaction rates and higher methane selectivity on narrow pore catalysts. Later, Liu et al. ${ }^{11}$ and Xiong et al. ${ }^{9}$ found that the large pore size of the catalyst improved the FTS catalytic activity. It is known that iron carbides are the active phase for FTS. It has been suggested that $\mathrm{H}_{2} \mathrm{O}$ produced by FTS reaction should be responsible for the oxidation of iron carbides. ${ }^{44,45}$ However, the large pore size of catalyst is helpful to effectively remove formed water and suppress reoxidation of iron carbides. In addition, the $\mathrm{H}_{2}$-TPD result indicates that addition of PVA in catalyst preparation process apparently improves the dispersion of catalyst, especially for $\mathrm{Fe}_{2} \mathrm{O}_{3}$-PVA-2 catalyst. Therefore, higher catalytic activity and stability are attributed to the large pore size, the large particle size and the high dispersion of catalyst due to addition of PVA in catalyst preparation process.

Effects of PVA concentration and temperature on product selectivity of catalysts under different temperatures are shown in Figure 11. Hydrocarbon product distributions

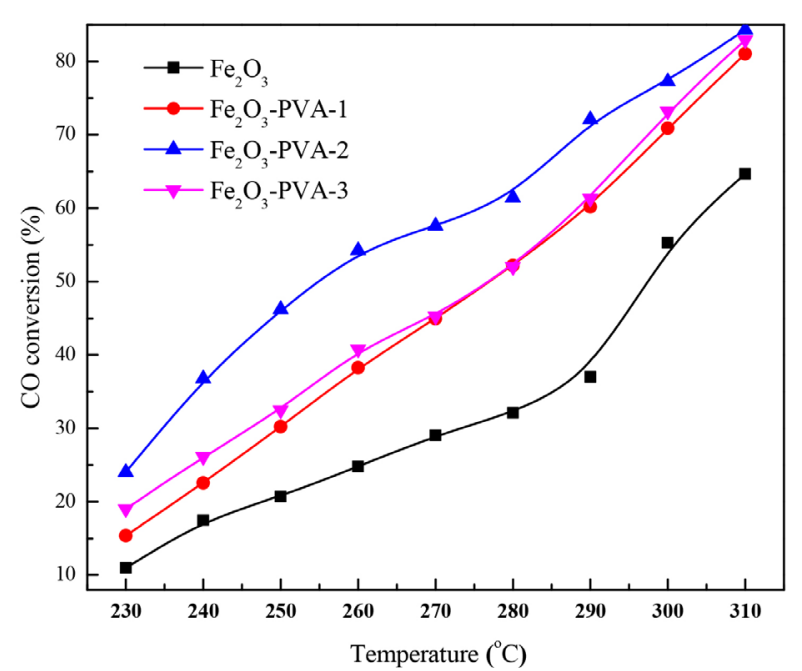

Figure 9. Effects of PVA concentration and temperature on $\mathrm{CO}$ conversion of catalysts.

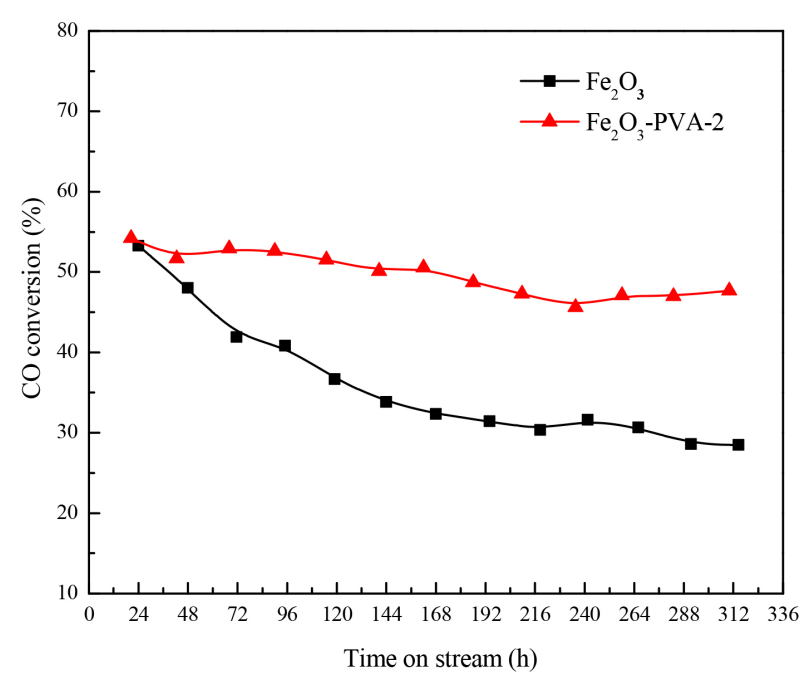

Figure 10. CO conversion as a function of time on stream of catalysts $\left(\mathrm{Fe}_{2} \mathrm{O}_{3}\right.$ : reaction temperature $300{ }^{\circ} \mathrm{C} ; \mathrm{Fe}_{2} \mathrm{O}_{3}$-PVA-2: reaction temperature $\left.260{ }^{\circ} \mathrm{C}\right)$.

of catalysts are summarized in Table 2 . The selectivity of methane over $\mathrm{Fe}_{2} \mathrm{O}_{3}$-PVA catalyst is lower than that over $\mathrm{Fe}_{2} \mathrm{O}_{3}$ catalyst, as shown in Figure 11a. In addition, selectivity of methane decreases with the increasing of PVA concentration and passes through a minimum at the PVA concentration of $15 \mathrm{wt} . \%$. Methane and $\mathrm{C}_{2}-\mathrm{C}_{4}$ are the main component in the hydrocarbon products due to high reaction temperature. Whilst the selectivity of $\mathrm{C}_{5}{ }^{+}$over the iron catalysts is lower. $\mathrm{Fe}_{2} \mathrm{O}_{3}$-PVA catalyst also shows a much higher $\mathrm{C}_{5}{ }^{+}$selectivity for FTS reaction than $\mathrm{Fe}_{2} \mathrm{O}_{3}$ catalyst, as shown in Figure 11b. It can be found that the selectivity of $\mathrm{C}_{5}{ }^{+}$increases with the increasing of PVA concentration and passes through a maximum at the PVA concentration of $15 \mathrm{wt} . \%$. It has been accepted that the increase in methane selectivity in narrow pore catalysts was attributed to the reducibility of the catalysts and a larger diameter of catalyst 
Table 2. Activity and selectivity of catalysts

\begin{tabular}{lccccccccccccc}
\hline Catalyst $^{\mathrm{a}}$ & \multicolumn{3}{c}{$\mathrm{Fe}_{2} \mathrm{O}_{3}$} & \multicolumn{3}{c}{$\mathrm{Fe}_{2} \mathrm{O}_{3}-\mathrm{PVP}-1$} & \multicolumn{3}{c}{$\mathrm{Fe}_{2} \mathrm{O}_{3}-\mathrm{PVP}-2$} & \multicolumn{3}{c}{$\mathrm{Fe}_{2} \mathrm{O}_{3}-\mathrm{PVP}-3$} \\
\hline Reaction temperature / ${ }^{\circ} \mathrm{C}$ & 230 & 270 & 310 & 230 & 270 & 310 & 230 & 270 & 310 & 230 & 270 & 310 \\
$\mathrm{TOF}^{\mathrm{b}} \times 10^{-3} / \mathrm{s}^{-1}$ & 0.18 & 0.48 & 1.07 & 0.27 & 0.80 & 1.44 & 0.45 & 1.00 & 1.57 & 0.34 & 0.80 & 1.46 \\
$\mathrm{CO}$ conversion / \% & 11.01 & 29.03 & 64.67 & 15.36 & 44.96 & 81.06 & 24.02 & 57.59 & 84.34 & 19.04 & 45.28 & 82.96 \\
$\mathrm{CO}+\mathrm{H}_{2}$ conversion / \% & 10.26 & 28.40 & 54.12 & 11.78 & 33.50 & 57.46 & 17.35 & 38.20 & 57.79 & 16.35 & 35.76 & 58.59 \\
$\mathrm{H}_{2} / \mathrm{CO}$ (in tail gas) & 2.26 & 2.26 & 3.20 & 2.36 & 2.89 & 6.27 & 2.53 & 3.32 & 7.75 & 2.33 & 2.78 & 6.83 \\
$\mathrm{~K}_{\mathrm{wGS}}$ & 1.63 & 0.90 & 2.96 & 1.98 & 2.68 & 9.00 & 2.27 & 3.63 & 10.56 & 2.50 & 2.37 & 9.30 \\
$\mathrm{CO}_{2}$ selectivity / (wt.\%) & 6.60 & 13.38 & 36.47 & 33.21 & 35.46 & 49.57 & 33.50 & 39.16 & 50.03 & 30.44 & 34.66 & 49.86 \\
$\mathrm{HC}$ selectivity / (wt.\%) & & & & & & & & & & & & \\
$\mathrm{C}_{1}$ & 16.82 & 19.63 & 28.00 & 9.88 & 14.22 & 25.97 & 5.93 & 11.09 & 22.82 & 7.80 & 13.96 & 24.58 \\
$\mathrm{C}_{2}-\mathrm{C}_{4}$ & 29.20 & 47.17 & 55.80 & 27.87 & 43.13 & 51.75 & 27.99 & 37.86 & 49.43 & 26.34 & 40.42 & 50.47 \\
$\mathrm{C}_{5}{ }^{+}$ & 53.98 & 33.21 & 16.19 & 62.25 & 42.65 & 22.28 & 66.07 & 51.05 & 27.75 & 65.86 & 45.61 & 24.95 \\
$\mathrm{C}_{2}-\mathrm{C}_{4} \mathrm{O} / \mathrm{P}$ & 0.81 & 0.33 & 0.19 & 2.00 & 0.76 & 0.48 & 2.61 & 1.23 & 0.67 & 2.05 & 0.81 & 0.58 \\
\hline
\end{tabular}

aReaction condition: $1.5 \mathrm{MPa}, \mathrm{H}_{2} / \mathrm{CO}=2.0$, and $\mathrm{GHSV}=2000 \mathrm{~h}^{-1}$; bapparent turnover frequency: numbers of $\mathrm{CO}$ molecules converted per adsorption site per second; $\mathrm{C}_{2}-\mathrm{C}_{4} \mathrm{O} / \mathrm{P}$ : olefin/paraffin ratio.

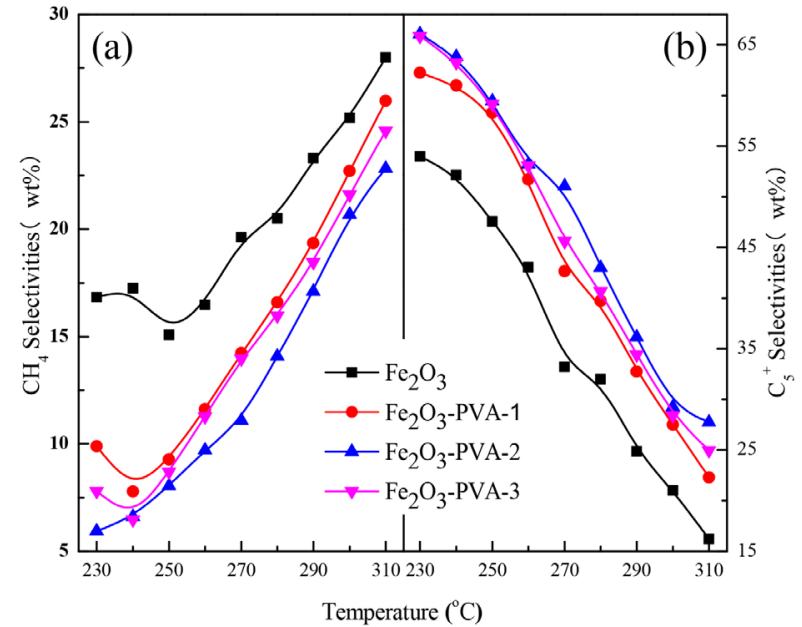

Figure 11. Effects of PVA concentration and temperature on product selectivity of catalysts: (a) $\mathrm{CH}_{4}$ selectivity; (b) $\mathrm{C}_{5}{ }^{+}$selectivity.

pores also led to significantly higher $\mathrm{C}_{5}{ }^{+}$selectivities. ${ }^{7,43,46,47}$ Therefore, the proper large pore size of the $\mathrm{Fe}_{2} \mathrm{O}_{3}$-PVA-2 catalyst may possess the highest $\mathrm{C}_{5}^{+}$selectivity and the lowest methane selectivity. As shown in Table 2, the $\mathrm{C}_{2}-\mathrm{C}_{4}$ olefin/paraffin $\left(\mathrm{C}_{2}-\mathrm{C}_{4} \mathrm{O} / \mathrm{P}\right)$ ratio decreases with increase of temperature for all catalysts. The $\mathrm{Fe}_{2} \mathrm{O}_{3}$-PVA catalyst has a higher $\mathrm{C}_{2}-\mathrm{C}_{4} \mathrm{O} / \mathrm{P}$ ratio than $\mathrm{Fe}_{2} \mathrm{O}_{3}$ catalyst. It indicates that the addition of PVA in catalyst preparation process can decrease methane selectivity and increase $\mathrm{C}_{5}{ }^{+}$selectivity of the iron-based catalyst in FTS reaction.

\section{Conclusions}

In this study, $\mathrm{Fe}_{2} \mathrm{O}_{3}$ catalysts were prepared by coprecipitation method with and without the assistance of
PVA. The $\mathrm{Fe}_{2} \mathrm{O}_{3}$-PVA catalyst has relative smaller BET surface area, larger pore size and large particle size than that of $\mathrm{Fe}_{2} \mathrm{O}_{3}$ catalyst. In addition, the structure of the $\mathrm{Fe}_{2} \mathrm{O}_{3}$-PVA catalyst can be controlled by tuning PVA concentrations during the catalyst preparation process.

The effect of PVA on reduction behavior of catalyst shifts to higher the reduction temperature either in $\mathrm{H}_{2}$ or in $\mathrm{CO}$ probably due to stronger iron oxides interaction. The addition of PVA in catalyst preparation process accelerates the carburization or the activation of catalyst in the $\mathrm{CO}$ or syngas atmosphere owing to large pore size and high dispersion of the $\mathrm{Fe}_{2} \mathrm{O}_{3}$-PVA catalyst.

In the FTS reaction, the $\mathrm{Fe}_{2} \mathrm{O}_{3}$-PVA catalyst showed higher catalytic activity and stability during time on stream than that of the $\mathrm{Fe}_{2} \mathrm{O}_{3}$ catalyst, owing to large pore size, large particle size and high dispersion of $\mathrm{Fe}_{2} \mathrm{O}_{3}$-PVA catalyst. Moreover, addition of PVA in catalyst preparation process also can significantly decrease methane selectivity and increase $\mathrm{C}_{5}{ }^{+}$selectivity of the iron-based catalyst in FTS reaction. In addition, an important finding is that a proper PVA concentration (15 wt.\%) apparently suppresses the methane selectivity and shows good stability in the FTS reaction.

\section{Acknowledgments}

The authors are indebted to the support from the National Natural Science Foundation of China (No. 21373254). This work is also supported by Wuhan Kaidi General Research Institute of Engineering \& Technology Co., Ltd. 


\section{References}

1. Bukur, D. B.; Lang, X.; Ind. Eng. Chem. Res. 1999, 38, 3270.

2. Dry, M. E.; Appl. Catal., A 2004, 276, 1.

3. Dry, M. E.; Catal. Today 2002, 71, 227.

4. Zhang, J.; Chen, J.; Ren, J.; Sun, Y.; Appl. Catal., A 2003, 243, 121.

5. Zhang, Y.; Shinoda, M.; Tsubaki, N.; Catal. Today 2004, 93, 55 .

6. Lapszewicz, J. A.; Loeh, H. J.; Chipperfield, J. R.; J. Chem. Soc., Chem. Commun. 1993, 913.

7. Tsubaki, N.; Zhang, Y.; Sun, S.; Mori, H.; Yoneyama, Y.; Li, X.; Fujimoto, K.; Catal. Commun. 2001, 2, 311.

8. Tao, C.; Li, J.; Liew, K. Y.; Sci. China: Chem. 2010, 53, 2551.

9. Xiong, H.; Zhang, Y.; Liew, K.; Li, J.; J. Mol. Catal. A: Chem. 2008, 295, 68 .

10. Liu, Y.; Fang, K.; Chen, J.; Sun, Y.; Green Chem. 2007, 9, 611.

11. Liu, Y.; Chen, J.; Fang, K.; Wang, Y.; Sun, Y.; Catal. Commun. 2007, 8, 945.

12. Liu, K.; Suo, H.; Zhang, C.; Xu, J.; Yang, Y.; Xiang, H.; Li, Y.; Catal. Commun. 2010, 12, 137.

13. Herranz, T.; Rojas, S.; Perez-Alonso, F.; Ojeda, M.; Terreros, P.; Fierro, J.; Appl. Catal., A 2006, 311, 66.

14. Calderone, V. R.; Shiju, N. R.; Curulla-Ferré, D.; Chambrey, S.; Khodakov, A.; Rose, A.; Thiessen, J.; Jess, A.; Rothenberg, G.; Angew. Chem., Int. Ed. 2013, 52, 4275.

15. Dong, H.; Xie, M.; Xu, J.; Li, M.; Peng, L.; Guo, X.; Ding, W.; Chem. Commun. 2011, 47, 4019.

16. Liu, Y.; Goebl, J.; Yin, Y.; Chem. Soc. Rev. 2013, 42, 2610.

17. Luo, M. F.; Ma, J. M.; Lu, J. Q.; Song, Y. P.; Wang, Y. J.; J. Catal. 2007, 246, 52.

18. Xie, L.; Hu, Z.; Lv, C.; Sun, G.; Wang, J.; Li, Y.; He, H.; Wang, J.; Li, K.; Electrochim. Acta 2012, 78, 205.

19. Gao, J.; Ye, K.; Yang, L.; Xiong, W. W.; Ye, L.; Wang, Y.; Zhang, Q.; Inorg. Chem. 2013, 53, 691.

20. Chu, Z.; Chen, H.; Yu, Y.; Wang, Q.; Fang, D.; J. Mol. Catal. A: Chem. 2013, 366, 48.

21. Mercier, L.; Pinnavaia, T. J.; Chem. Mater. 2000, 12, 188.

22. Ma, C.; Chen, Y.; Chen, J.; J. Braz. Chem. Soc. 2015, 26, 1520.

23. Bukur, D. B.; Carreto-Vazquez, V.; Pham, H. N.; Datye, A. K.; Appl. Catal., A 2004, 266, 41.

24. Wang, H.; Yang, Y.; Xu, J.; Wang, H.; Ding, M.; Li, Y.; J. Mol. Catal. A: Chem. 2010, 326, 29.
25. Ning, W. S.; Koizumi, N.; Chang, H.; Mochizuki, T.; Itoh, T.; Yamada, M.; Appl. Catal., A 2006, 312, 35.

26. Suo, H.; Zhang, C.; Wu, B.; Xu, J.; Yang, Y.; Xiang, H.; Li, Y.; Catal. Today 2012, 183, 88.

27. Lox, E. S.; Froment, G. F.; Ind. Eng. Chem. Res. 1993, 32, 71.

28. Huang, C. S.; Xu, L.; Davis, B. H.; Fuel Sci. Technol. Int. 1993, 11,639

29. Suo, H.; Wang, S.; Zhang, C.; Xu, J.; Wu, B.; Yang, Y.; Xiang, H.; Li, Y. W.; J. Catal. 2012, 286, 111.

30. Jin, Y.; Datye, A. K.; J. Catal. 2000, 196, 8.

31. Zhang, C. H.; Yang, Y.; Teng, B. T.; Li, T. Z.; Zheng, H. Y.; Xiang, H. W.; Li, Y. W.; J. Catal. 2006, 237, 405.

32. Moritz, W.; Imbihl, R.; Behm, R. J.; Ertl, G.; Matsushima, T.; J. Phys. Chem. 1985, 83, 1959.

33. Bernasek, S. L.; Zappone, M.; Jiang, P.; Surf. Sci. 1992, 272, 53.

34. Walch, S. P.; Surf. Sci. 1984, 143, 188.

35. Yoshida, K.; Somorjai, G.; Surf. Sci. 1978, 75, 46.

36. Merrill, P. B.; Madix, R. J.; Surf. Sci. 1996, 347, 249.

37. Wedler, G.; Borgmann, D.; Geuss, K.-P.; Surf. Sci. 1975, 47, 592.

38. Zhang, M.; Fang, K.; Lin, M.; Hou, B.; Zhong, L.; Zhu, Y.; Wei, W.; Sun, Y.; J. Phys. Chem. C 2013, 117, 21529.

39. Cozar, O.; Leopold, N.; Jelic, C.; Chiş, V.; David, L.; Mocanu, A.; Tomoaia-Cotişel, M.; J. Mol. Struct. 2006, 788, 1.

40. Li, S.; Zhu, H.; Qin, Z.; Wang, G.; Zhang, Y.; Wu, Z.; Li, Z.; Chen, G.; Dong, W.; Wu, Z.; Appl. Catal., B 2014, 144, 498.

41. Kavitha, M. K.; John, H.; Gopinath, P.; Mater. Res. Bull. 2014, 49, 132.

42. Anderson, R. B.; Hall, W. K.; Krieg, A.; Seligman, B.; J. Am. Chem. Soc. 1949, 71, 183.

43. Khodakov, A. Y.; Griboval-Constant, A.; Bechara, R.; Zholobenko, V. L.; J. Catal. 2002, 206, 230.

44. Bukur, D. B.; Okabe, K.; Rosynek, M. P.; Li, C. P.; Wang, D. J.; Rao, K. R. P. M.; Huffman, G. P.; J. Catal. 1995, 155, 353.

45. Li, S.; O’Brien, R. J.; Meitzner, G. D.; Hamdeh, H.; Davis, B. H.; Iglesia, E.; Appl. Catal., A 2001, 219, 215.

46. Khodakov, A. Y.; Griboval-Constant, A.; Bechara, R.; Villain, F.; J. Phys. Chem. B 2001, 105, 9805.

47. Ma, C.; Chen, J.; Catal. Lett. 2015, 145, 702.

Submitted: June 27, 2016 Published online: January 30, 2017 